Journal of Teacher Education for Sustainability, vol. 21, no. 2, pp. 121-138, 2019

\title{
Willingness to Communicate, Possible Selves, Learner Autonomy, and Academic Target Needs: Implications for Sustainable Development in L2 Pedagogy
}

\author{
Rajab Esfandiari and Sepideh Hesani \\ Imam Khomeini International University, Qazvin, Iran
}

\begin{abstract}
Life-long learning requires that language learners be well prepared for the target situations they will be operating in. To achieve this goal and to improve education for sustainable development, language teachers and language educators need to motivate language learners to participate in the target language. The present study, therefore, investigated the relationships between willingness to communicate (WTC) and possible selves, WTC and learner autonomy, and WTC and academic target needs in an English for Academic Purposes (EAP) context to open up new horizons for sustainable L2 learning. In addition, the present study was aimed at examining the extent to which WTC, possible selves, and learner autonomy would predict academic target needs. Five hundred and ninety male and female undergraduate students from two state-run universities in Iran participated in this study. The present study used four questionnaires to collect the data, and SPSS (version 25) was used to analyze the data. The findings showed a significant positive relationship between WTC and possible selves. Finally, results from hierarchical multiple regression revealed that WTC, possible selves, and learner autonomy were predictors of academic target needs. The findings suggest that the interplay of several variables should be considered if language learners need to actively communicate in L2 academic settings. Implications for sustainable development in L2 pedagogy are also discussed.
\end{abstract}

Key words: learner autonomy, possible selves, target needs, sustainable learning

\section{Introduction}

The importance of learners' verbalization in language learning is a generally accepted tenet. Considering the importance of interaction, students need to be willing to use the target language in language classes (Kang, 2005). Learners' high degree of WTC contributes to better understanding of L2 (Zhang et al., 2018). Sato (2017) claimed that the higher a learners' WTC, the better their fluency in L2. Thus, pedagogical significance of exploring WTC to express intended meaning in the target language is the main purpose of language learning. 
However, most language teachers have the experience of investing energy for their students without getting any positive feedback. Students may not eager to use the target language, are not motivated to listen to each other (Eddy-U, 2015), are over-reliant on the teachers (Zhou, 2016), and do not have precise understanding of their needs (Belcher, 2006). Therefore, providing opportunities for learners to use the target language, creating motivation, encouraging learners to become autonomous, and considering their needs, are of great importance.

As previous studies have shown, encouraging learners to become motivated and autonomous learners influences their WTC (Eddy-U, 2015). It is also noteworthy to find how EAP learners effectively function in the target situation (Hutchinson \& Waters, 1987). Creating and enhancing awareness of how EAP learners communicate based on their target needs can also be helpful. Therefore, studying these issues helps us have a better view of how these factors influence EAP students' WTC.

Studies carried out in the area of WTC in different contexts, with different learners, and with different purposes have highlighted the importance of WTC. Various studies have investigated the relationship between WTC and motivation or WTC and autonomy; however, there are few studies on the possible relationships among WTC, possible selves, learner autonomy, and target needs in an EAP context. On top of this, sustainable L2 learning needs to understand the current status of the possible relationships among WTC, possible selves, learner autonomy, and target needs in an EAP context. Given that, conducting such an investigation with the purpose of obtaining the current status of these issues and opening new horizons for the future researchers to look at sustainability in L2 pedagogy is important. That said, this study is to investigate the relationships between these variables in an EAP context. The study set out to answer the following research questions:

1. Is there any significant relationship between WTC and possible selves in an EAP context?

2. Is there any significant relationship between WTC and learner autonomy in an EAP context?

3. Is there any significant relationship between WTC and leaners' academic target needs in an EAP context?

4. Are WTC, learner autonomy, and possible selves predictors of language learners' academic target needs?

\section{Literature Review}

\section{Willingness to Communicate}

WTC in L2 contexts is defined as "a readiness to enter into discourse at a particular time with a specific person or persons using an L2" (Dornyei, 2005, p. 547). The definition indicates a dual characteristic: (a) trait or stable, and (b) state or dynamic (Peng \& Woodrow, 2010). Trait WTC refers to general individuals' communication tendency, while dynamic WTC is defined as individuals' fluctuated communicative behaviors (Zhang et al., 2018).

Early research on WTC focused on its trait characteristics. Most of these studies measured learners' trait WTC by using questionnaires with large sample sizes (e.g., MacIntyre \& Doucette, 2010). Since WTC was conceptualized as trait-based, numerous 
attempts were undertaken to identify factors responsible for variation in the degree of WTC. Some individual variables, including personality, communication confidence, motivation, gender and age, and social context have been found to affect WTC (Piechurska-Kuciel, 2017).

\section{L2 Motivational Self-System}

In order to determine an alternative approach ensuring a better understanding of L2 learners' motivation, Dornyei $(2005,2009)$ proposed the L2 motivational self-system, which focused on 'possible selves' (Kong et al., 2018). Dornyei (2005) believes that motivational-self mechanism represents "the individual's ideas of what they might become, what they would like to become and, what they are afraid of becoming” (p. 98). This model has three dimensions: ideal L2 self, ought to L2 self, and L2 learning experience.

The ideal L2 self is the key construction in L2 motivational self-system. As Dornyei (2005) points out, ideal L2 self refers to "the L2-spesific aspect of one's ideal self" (p. 105). Ideal L2 self includes integrative motives and instrumental and internalized motives (Yung, 2019). It represents the positive image of using language in the future. For example, learners who have developed a vivid ideal L2 self are likely to endeavor to learn L2 by imagining themselves communicating fluently in the future (Kong et al., 2018). Thus, ideal L2-self enables students to develop a salient vision of oneself in the future as an attractive, competent, and successful L2 user (Noels, 2003).

Another dimension in L2 motivational self-system is ought-to L2 self. According to Magid (2013), the ought-to L2 self is defined as "the attribute that one believes one ought to possess in order to avoid possible negative outcomes" (p. 229). For instance, if a person wants to learn a language in order to live up the expectation of his/her parents or teachers, the ought-to L2 self can act as a motivator for L2 learning (Papi, 2010). The ought-to L2 self is considered extrinsic constituent in Noels (2003) and Ushioda' (2011) taxonomies (Dornyei, 2009).

\section{Learner Autonomy}

The ultimate goal of students in language learning is to become fully autonomous. In this regard, cognitive psychologists emphasize the role of learner in the learning process than teachers and materials. As Brown, Collins, and Duguid (1990) argued, learners should be involved in decision making rather than just gaining knowledge during lessons. What the teacher does and what the textbook provides are not important because it is the learner who does the learning. According to Scharle and Szabo (2000), autonomy changes attitudes and transfers roles to learners. The shift of responsibility from teachers to learners is generally referred to as "learner's autonomy" (Cotterall \& Crabbe, 1999, p. 3).

Developing learners' autonomy does not mean that teachers leave learners to their own devices; instead, teachers should encourage learners to take control of their learning. Benson (2001) classified six approaches to developing learner autonomy. These approaches include (a) resource-based approaches, (b) technology-based approaches, (c) teacherbased approaches, (d) classroom-based approaches, (e) curriculum-based approaches, and (f) learner-based approaches. 


\section{Academic Needs}

Needs are the heart of the EAP research. Basturkman (2006) defined needs as "the reasons that cause a learner to learn language" (p. 15). Brindley (1989) also made a distinction between the product-oriented needs which considered what the learners have to do at the end of the language course, and the process-oriented needs referring to what learners need to do to learn the language. Dudley-Evans and St Johns (1998) suggested three broad categories of needs: learning situation analysis (LSA), present situation analysis (PSA), and target situation analysis (TSA).

TSA is like an umbrella term, which centers on identifying learners' needs. According to Robinson (1991), "a need analysis, which focuses on students' needs at the end of a language course, can be called target needs" (p. 8). As maintained by Hutchinson and Waters (1987), TSA refers to the activities learners do in the target situation, which is product-oriented in nature. Accordingly, Dudley-Evans and St John (1998) placed objective, perceived, and product-oriented needs under TSA.

\section{L2 Pedagogy for Sustainability}

It can be said that the importance of L2 learning is an axiomatic fact due to the connection existing between L2 learning and the notions of thinking, memory, and expressions (Zygmunt, 2016). To communicate on environmental issues, individuals need to use language (Alghamdi \& El-Hassan, 2019). Nowadays, EAP helps individuals with different languages to negotiate globally on different issues. Consequently, addressing factors that are important in EAP contexts is critical to establish a sustainable L2 pedagogy; conducive for negotiating sustainable concepts. However, to the best knowledge of the authors, to date, there were no study aiming for this issue. Thus, the current study aims to open up a new direction for the future research by addressing the issue of sustainability in an EAP context.

\section{Method}

\section{Participants}

Five hundred and ninety Iranian undergraduate students were conveniently selected to fill out the questionnaires in this study, but questionnaires from 577 students were used for data analysis. Thirteen students dropped out from the final analysis because they were outliers. The students ranged from 18 to 21 years of age, with a mean age range of 3.44 and standard deviation of .904. Among them, 279 were male, and 298 were female. The majority of them (411 students) did not have the experience of English language learning.

Students were majoring in diverse fields of study. The fields included engineering, sociology, historiography, political science, Arabic translation, accounting, law, geology, philosophy, physical education, statistics, metalogy, architecture, urban engineering, psychology, industrial management, physics, mathematics, chemistry, literature, mechanic, petroleum engineering, computer science, air and space, and industrial engineering at Imam Khomeini International University in Qazvin, Iran, and Sharif Technology University in Tehran, Iran. 


\section{Instruments}

In order to collect data for the study, the present researchers used four questionnaires: (1) willingness to communicate questionnaire, (2) possible selves questionnaire, (3) learner autonomy questionnaire, and (4) target needs questionnaire. Detailed information about these questionnaires is given below.

L2 willingness to communicate questionnaire developed by MacIntyre et al. (2001) was used to assess the participants' degree of WTC. This questionnaire consists of 27 items; it is based on a 5-point Likert-scale, ranging from almost never willing (1) to almost always willing (5). The items written for this questionnaire were grouped into four skill areas, and each skill contained a certain number of items. The alpha levels indicate that reliability estimates were within the acceptable range: speaking ( 8 items, $\alpha=.81$ ), comprehension (5 items, $\alpha=.83$ ), reading (6 items, $\alpha=.83$ ), and writing ( 8 items, $\alpha=.88)$. It took the participants 12 minutes to fill out the questionnaire.

The reliability of WTC questionnaire in this study was estimated to be 0.94 . The alpha levels indicate reliability estimates within the acceptable range: speaking ( 8 items, $\alpha=.85$ ), reading (6 items, $\alpha=.88$ ), writing ( 8 items, $\alpha=.87$ ), and listening (5 items, $\alpha=.84$ ).

Possible selves questionnaire, developed by Papi (2010) based on Dornyei's (2003) guidelines, was used to assess the main variables of the L2 motivational self-system. This questionnaire consists of 18 items; it is based on a 6-point Likert scale, ranging from strongly disagree (1) to strongly agree (6) for statement type items, and from not at all (1) to very much (6) for question-type items.

The questionnaire has three dimensions: ideal L2 self, which includes items from 1 to 6 with the Cronbach alpha reliability coefficient of 0.77 ; ought-to L2 self, which includes items from 7 to 12, with the Cronbach alpha of 0.71 ; and L2 learning experience, which includes items from 13 to 18 , with the Cronbach alpha of 0.85 . It took the participants approximately 8 minutes to fill out the questionnaire. The reliability of possible selves questionnaire was estimated to be 0.89 in the present study. The alpha levels indicate reliability estimates within the acceptable range: ideal L2 self (items 1 to 6, $\alpha=.91$ ), ought to L2 self (items 7 to $12, \alpha=.90$ ), and learning experience (items 13 to $18, \alpha=.90)$.

Learner autonomy questionnaire (LAQ), developed by Zhang and Li (2004), was used to measure learner autonomy. This questionnaire consists of 21 items. The questionnaire has two parts. Part one of the questionnaire consists of 11 items; it is a 5-point Likert-scale, ranging from never (1) to always (5). Part two of the questionnaire consists of 10 items in multiple-choice format. The participants chose the closest answer to their beliefs, their attitudes, or ideas. The participants' choices in the questionnaire were the scores from A to E that corresponded to 1, 2, 3, 4, and 5, respectively. It took the participants approximately 10 minutes to fill out the questionnaire. The questionnaire was proven to have high content validity. According to Zhang and Li (2004), the Cronbach alpha for this questionnaire was estimated to be 0.80 . The reliability of learner autonomy questionnaire in this study was estimated to be 0.74 .

Needs analysis questionnaire developed by Soodmand Afshar and Movassagh (2016) was used to measure EAP students' needs. Several approaches were followed in the validation process of the questionnaire. First, the main items of the questionnaire were adopted from some valid and reliable instruments already existing in the literature, 
mainly from Mazdayasna and Tahririan (2008). Second, three experts in the field were asked to give their ideas on the items incorporated and those needing to be included or excluded. Third, the questionnaire was pilot tested with a group of 120 similar students who were requested to give their ideas about the questions and check for the ambiguities of the items. The necessary changes indicated by the experts in the second step and respondents in the third step were accordingly made. Next, a principal component factor analysis with Varimax rotation was run, the results of which ensured the validity of the questionnaire with the KMO being 0.79 . Therefore, the construct validity of the questionnaire was confirmed in the original study.

This questionnaire consists of 35 items; it is based on a 5-point Likert-scale, ranging from strongly disagree (1) to strongly agree (5). The Cronbach for this questionnaire is 0.815 . For the purpose of the study, part one of the questionnaire, which includes 21 items, was used, and Cronbach alpha estimated was 0.93. It took the participants approximately 10 minutes to fill out the questionnaire. The reliability of needs analysis questionnaire was estimated to be 0.91 .

\section{Data Analysis}

The questionnaire data for this study were analyzed quantitatively. SPSS (version 25 ) was used to analyze the data. Descriptive statistics were used to analyze demographic information. To check the lack of univariate outliers, the standardized scores (Z-scores) were computed for WTC, possible selves, learners' academic target needs, and learner autonomy. Moreover, the assumption of normality was checked through skewness and kurtosis indices. Using SPSS, Pearson correlation was run in order to see if there was any significant relationship between WTC and possible selves, WTC and learner autonomy, WTC and academic target needs. In addition, hierarchical multiple regression was run to find the predictors of academic target needs.

\section{Results}

\section{Investigation of the First Research Question}

The first research question of the present research was concerned with whether there was any significant relationship between WTC and possible selves in an EAP context. Using SPSS, Pearson correlation was run. Table 1 presents the correlation coeficient.

The assumptions of linearity and homoscedasticity were checked through scatter plot (Figure 1). Since the spread of dots fell along the diagonal and did not form any rising-and-falling patterns, it could be concluded that the assumption of linearity was retained. WTC and the possible selves enjoyed homogenous variances. The spread of dots did not form a funnel shape, i.e., narrow at one end and wide at the other.

As Table 1 shows, there is a moderate, positive correlation between WTC and possible selves $\left(r=.588, n=577, p=.000, R^{2}=.345\right)$ with a medium effect size. Therefore, the first null hypothesis of the present study is rejected, implying that the more willing to communicate students are, the more motivated they will be and vice versa. 


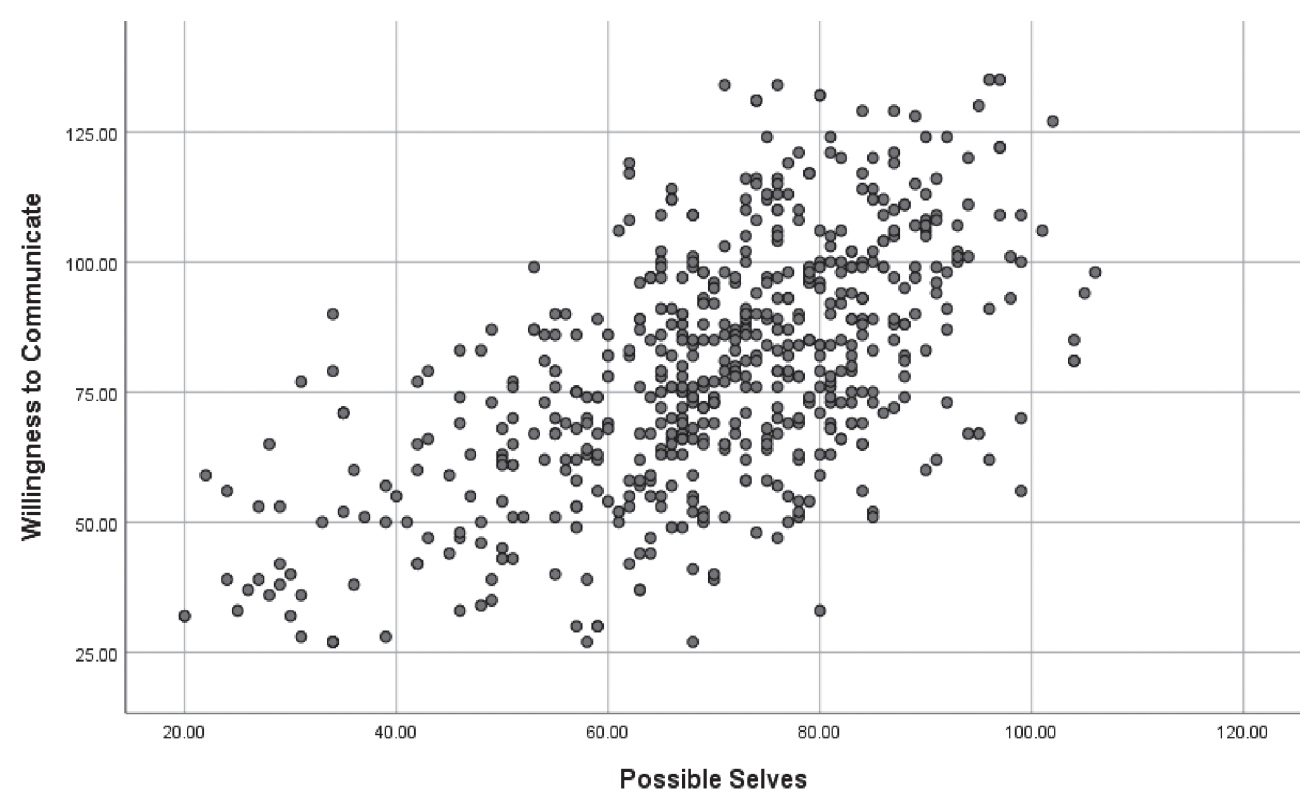

Figure 1. Scatter plot showing the relationship between WTC and possible selves

Table 1

Pearson Correlation between Possible Selves and WTC

\begin{tabular}{llc}
\hline \multirow{3}{*}{ Willingness to Communicate } & & Pearsible Selves \\
\cline { 2 - 3 } & Sig. (2-tailed) & $.588^{* * *}$ \\
\cline { 2 - 3 } & $\mathrm{N}$ & .000 \\
\hline
\end{tabular}

$* *$. Correlation is significant at the 0.01 level (2-tailed).

To understand the relationship between WTC and components of possible selves, ideal L2 self, ought-to L2 self, and learning experience, Pearson correlation was employed. As Table 2 shows, there is a significant positive relationship between WTC and ideal L2 self $\left(r=.624, n=577, p=.000, R^{2}=0.389\right)$ and WTC and learning experience $(r=.617$, $\left.n=577, p=.000, R^{2}=0.380\right)$. However, the relationship between WTC and ought-to L2 self is not statistically significant $(r=.042, n=577, p=.311)$.

Table 2

Pearson Correlation between Possible Selves and WTC

\begin{tabular}{llccc}
\hline & & Ideal L2 self & Ought-to L2 self & L2 learning experience \\
\hline WTC & Pearson Correlation & $.624^{* *}$ & $.042^{* *}$ & $.617^{* * *}$ \\
\hline & Sig. (2-tailed) & .000 & .311 & .000 \\
\hline $\mathrm{N}$ & 577 & 577 & 577 \\
\hline
\end{tabular}

$*$. Correlation is significant at the 0.01 level (2-tailed). 
Table 3

Pearson Correlation between Learner Autonomy and WTC

\begin{tabular}{llc}
\hline & & Learner Autonomy \\
\hline \multirow{3}{*}{ Willingness to Communicate } & Pearson Correlation & $.647^{* *}$ \\
\cline { 2 - 3 } & Sig. (2-tailed) & .000 \\
\cline { 2 - 3 } & $\mathrm{N}$ & 577 \\
\hline
\end{tabular}

$* *$. Correlation is significant at the 0.01 level (2-tailed).

\section{Investigation of the Second Research Question}

The second research question asked if there was any significant relationship between WTC and learner autonomy in an EAP context. Pearson correlation was run to examine the relationship. The results in Table $3\left(r=.647, n=577, p=.000, R^{2}=.418\right)$ indicated that there was a statistically significant relationship between the two variables, with a medium effect size. Thus, the second null hypothesis as there was not any significant relationship between WTC and learner autonomy in an EAP context was rejected, meaning that the more willing to communicate students were, the more autonomous they would be and vice versa.

The assumptions of linearity and homoscedasticity were checked through scatter plot (Figure 2). Since the spread of dots fell along the diagonal and did not form any rising-and-falling patterns, it could be concluded that the assumption of linearity was retained. WTC and the learner autonomy enjoyed homogenous variances. The spread of dots did not from a funnel shape, i.e., narrow at one end and wide at the other.

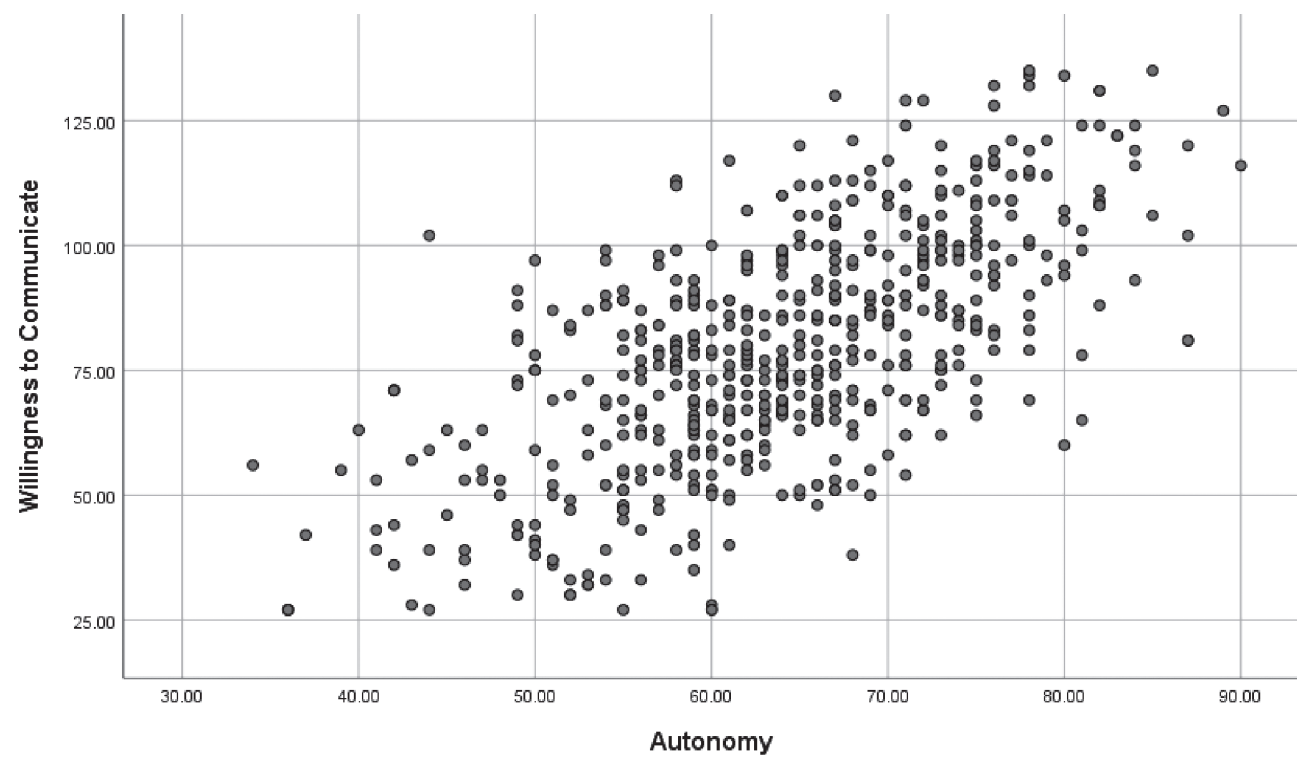

Figure 2. Scatter plot showing the relationship between WTC and learner autonomy 


\section{Investigation of the Third Research Question}

The third research question of the present research was concerned with whether there was any significant relationship between WTC and academic target needs in an EAP context. Using SPSS, Pearson correlation was run. Table 8 presents the correlation coefficient.

As Table 4 shows, there was a moderate, positive correlation between WTC and target needs $\left(r=.513, n=577, p=.000, R^{2}=.263\right)$ with a medium effect size. Therefore, the third null hypothesis of the present study was rejected, implying that the more willing to communicate students were, the better they would operate in future EAP settings and vice versa.

Table 4

Pearson Correlation between Target Needs and WTC

\begin{tabular}{llc}
\hline & & Target Needs \\
\hline \multirow{3}{*}{ Willingness to Communicate } & Pearson Correlation & $.513^{* *}$ \\
\cline { 2 - 3 } & Sig. (2-tailed) & .000 \\
\cline { 2 - 3 } & $\mathrm{N}$ & 577 \\
\hline
\end{tabular}

$* *$. Correlation is significant at the 0.01 level (2-tailed).

The assumptions of linearity and homoscedasticity were checked through scatter plot (Figure 3). Since the spread of dots fell along the diagonal and did not form any rising-and-falling patterns, it could be concluded that the assumption of linearity was retained. WTC and the target needs enjoyed homogenous variances. The spread of dots did not form a funnel shape, i.e., narrow at one end and wide at the other.

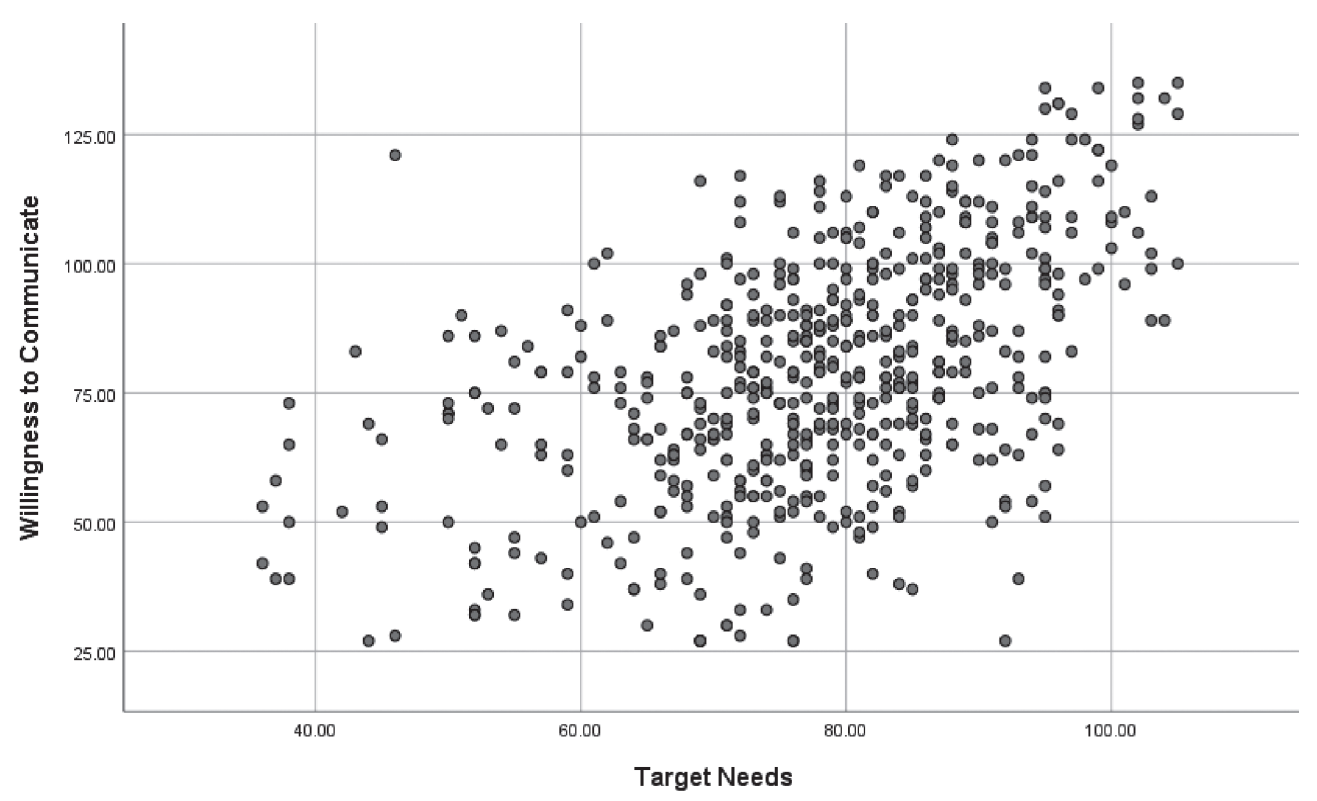

Figure 3. Scatter plot showing the relationship between WTC and target needs 


\section{Investigation of the Fourth Research Question}

The last research question of the present study was concerned with whether WTC, learner autonomy, and possible selves could predict language learners' academic target needs. Hierarchical multiple regression was run to predict EAP learners' target needs through WTC, autonomy and possible selves. As displayed in Table 5, the regression model converged in three steps. Learner autonomy entered the regression model in the first step to predict $28.6 \%$ of academic target needs $\left(R=.535, R^{2}=.286\right)$. This amount of prediction enjoyed statistical significance $\left(F_{(1,575)}=230.051, p=.000\right)$.

Table 5

Model Summary; Predicting Target Needs through WTC, Possible Selves and Learner Autonomy

\begin{tabular}{|c|c|c|c|c|c|c|c|c|c|c|}
\hline \multirow[b]{2}{*}{ Model } & \multirow[b]{2}{*}{$\mathrm{R}$} & \multirow[b]{2}{*}{ 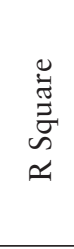 } & \multirow[b]{2}{*}{ 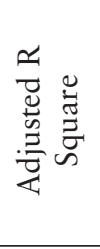 } & \multirow[b]{2}{*}{ 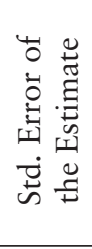 } & \multicolumn{5}{|c|}{ Change Statistics } & \multirow[b]{2}{*}{ 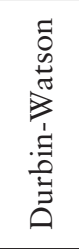 } \\
\hline & & & & & 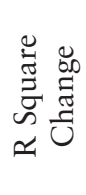 & $\begin{array}{c}\infty \\
\underset{I}{\Xi} \\
\underset{U}{\Xi}\end{array}$ & $\vec{t}$ & $\underset{t}{\mathbb{Z}}$ & $\begin{array}{l}\tilde{D} \\
\text { Jే } \\
\tilde{J} \\
\omega \\
\dot{\omega}\end{array}$ & \\
\hline 1 & $.535^{\mathrm{a}}$ & .286 & .285 & 11.24 & .286 & 230.05 & 1 & 575 & .000 & \\
\hline 2 & $.585^{\mathrm{b}}$ & .342 & .340 & 10.8 & .056 & 49.06 & 1 & 574 & .000 & \\
\hline 3 & $.603^{\mathrm{c}}$ & .364 & .360 & 10.63 & .022 & 19.47 & 1 & 573 & .000 & 1.920 \\
\hline
\end{tabular}

a. Predictors: (Constant), Autonomy

b. Predictors: (Constant), Autonomy, Possible Selves

c. Predictors: (Constant), Autonomy, Possible Selves, Willingness to Communicate

d. Dependent Variable: Target Needs

Possible selves entered the regression model in the second step to increase prediction to $34.2 \%\left(R=.585, R^{2}=.342\right)$. This amount of increase in prediction enjoyed statistical significance $\left(F_{(1,574)}=49.066, p=.000\right)$. Finally, WTC entered the regression model in the third step to increase prediction to $36.4 \%\left(R=.603, R^{2}=.364\right)$. This amount of increase in prediction enjoyed statistical significance $\left(F_{(1,573)}=19.472, p=.000\right)$.

Table 5 also displays the Durbin-Watson index, which can be used to test the assumption of independence of errors. Since the present cases did not show any meaningful sequence (time series), there was no need to report this statistic (Field, 2018).

Table 6

ANOVA $^{a}$

\begin{tabular}{llccccc}
\hline & Model & Sum of Squares & df & Mean Square & F & Sig. \\
\hline \multirow{2}{*}{1} & Regression & 29079.225 & 1 & 29079.225 & 230.051 & $.000^{\mathrm{b}}$ \\
\cline { 2 - 7 } & Residual & 72681.995 & 575 & 126.403 & & \\
\cline { 2 - 7 } & Total & 101761.220 & 576 & & & \\
\hline 2 & Regression & 34802.841 & 2 & 17401.420 & 149.173 & $.000^{\mathrm{c}}$ \\
\cline { 2 - 7 } & Residual & 66958.379 & 574 & 116.652 & & \\
\cline { 2 - 6 } & Total & 101761.220 & 576 & & & \\
\hline
\end{tabular}


Continuation of Table 6

\begin{tabular}{llccccc}
\hline 3 & Regression & 37003.431 & 3 & 12334.477 & 109.140 & $.000^{\mathrm{d}}$ \\
\cline { 2 - 6 } & Residual & 64757.790 & 573 & 113.015 & & \\
\hline Total & 101761.220 & 576 & & & \\
\hline
\end{tabular}

a. Dependent Variable: Target Needs

b. Predictors: (Constant), Autonomy

c. Predictors: (Constant), Autonomy, Possible Selves

d. Predictors: (Constant), Autonomy, Possible Selves, Willingness to Communicate

According to Table 6, the results of the ANOVA test show that the predictive power of the model is statistically significant for all three independent variables: Learner autonomy $\left(F_{(1,575)}=230.051, p<.000\right)$, learner autonomy and possible selves $\left(F_{(2,574)}=149.173, p<.000\right)$, and learner autonomy, possible selves, and WTC $\left(F_{(3,573)}=149.173, p<.000\right)$.

Table 7 displays the standardized (Beta) and unstandardized (B) regression coefficients.

These two indices can be used to predict the amount of change in the dependent variable, i.e., academic target needs. For example, the unstandardized regression coefficient for learner autonomy is .362. That is to say, if learner autonomy increases one unit, academic target needs increase .362 units. The standardized regression coefficient for the same variable is .271. That is to say, if learner autonomy increases one standard deviation, academic target needs increase .271 standard deviations. The results indicated that all predictors enjoyed significant prediction power, as shown below:

- Learner autonomy $(B=.362$, Beta $=.271, t=5.87, p=.000)$,

- Possible selves $(B=.183$, Beta $=.225, t=5.17, p=.000)$, and

- $\quad$ WTC $(B=.117$, Beta $=.208, t=4.41, p=.000)$.

Table 7

Regression Coefficients

\begin{tabular}{|c|c|c|c|c|c|c|}
\hline & \multirow{2}{*}{ Model } & \multicolumn{2}{|c|}{ Unstandardized Coefficients } & \multirow{2}{*}{$\frac{\text { Standardized Coefficients }}{\text { Beta }}$} & \multirow{2}{*}{$\mathrm{t}$} & \multirow{2}{*}{ Sig. } \\
\hline & & $\mathrm{B}$ & Std. Error & & & \\
\hline \multirow[t]{2}{*}{1} & (Constant) & 32.152 & 3.051 & & 10.537 & .000 \\
\hline & Autonomy & .714 & .047 & .535 & 15.167 & .000 \\
\hline \multirow[t]{3}{*}{2} & (Constant) & 30.053 & 2.946 & & 10.200 & .000 \\
\hline & Autonomy & .489 & .055 & .366 & 8.819 & .000 \\
\hline & Possible Selves & .236 & .034 & .291 & 7.005 & .000 \\
\hline \multirow[t]{4}{*}{3} & (Constant) & 32.623 & 2.958 & & 11.028 & .000 \\
\hline & Autonomy & .362 & .062 & .271 & 5.874 & .000 \\
\hline & Possible Selves & .183 & .035 & .225 & 5.174 & .000 \\
\hline & WTC & .117 & .027 & .205 & 4.413 & .000 \\
\hline
\end{tabular}

a. Dependent Variable: Target Needs

The assumption of linearity of the regression model was retained. As displayed through scatter plot (Figure 4), the spread of dots did not form any curve trend. 


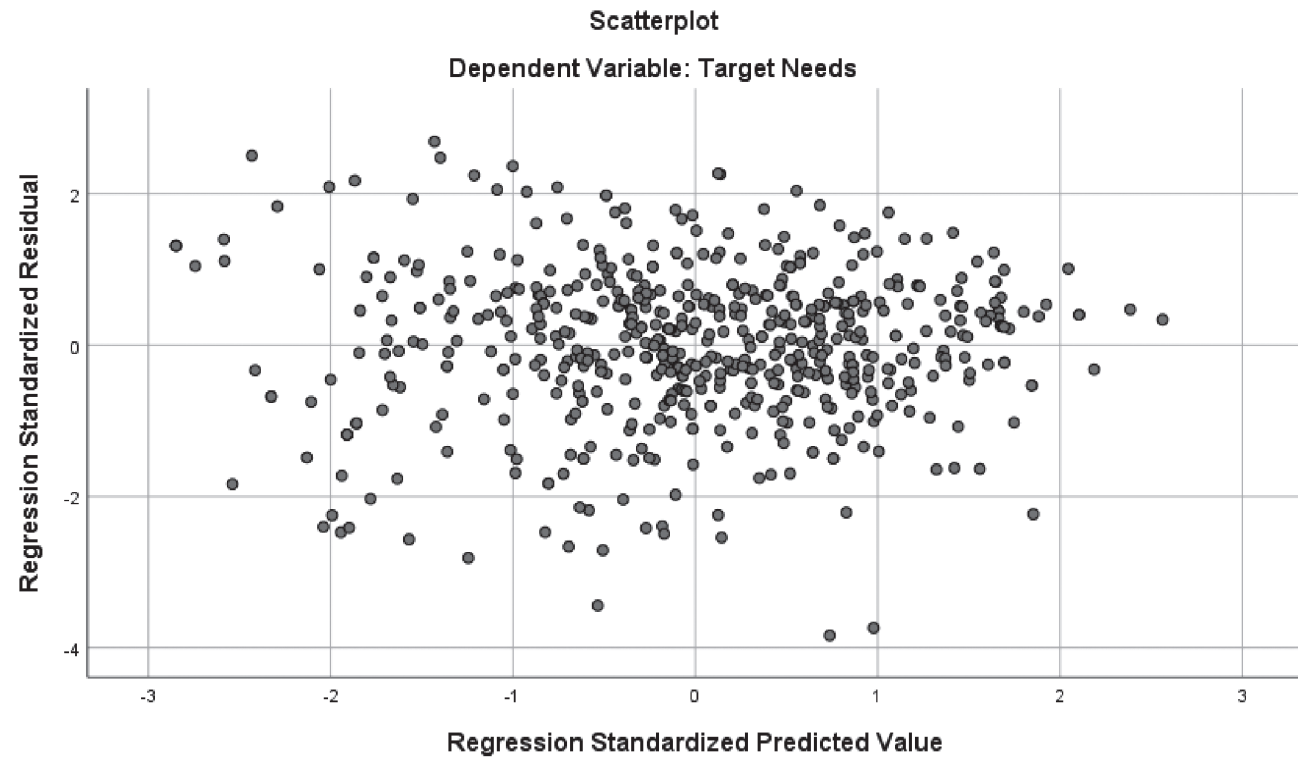

Figure 4. Test of linearity and homoscedasticity of regression model

The spread of dots also did not form any funnel shape. That is to say, the assumption of homoscedasticity was met.

\section{Discussion}

Based on the results of statistical analysis, the findings revealed that WTC positively correlated with possible selves. This finding supports that of $\mathrm{Oz}$ and Bursali (2017), who found that as the level of learners' ideal-12 self increased, they became more willing to communicate. The finding is also in line with previous studies, which indicated positive correlation between WTC and possible selves (Al-Murtadha, 2019; Munezane, 2015; Oz, 2016; Oz \& Bursali, 2018; Peng, 2015).

In terms of the dimensions of possible selves and WTC, the results of the current study are also consistent with the study conducted by Peng (2015), who found that the relationship between WTC and ideal L2 self was significant and positive. On the other hand, no relationship between these students' ought-to L2 selves and their L2 WTC was found. The outcome of the present research is consistent with that of $\mathrm{Oz}$ and Bursali (2018), who found that the relationship between the ought-to L2 self and L2 WTC was not statistically significant. Finally, the results of the study indicated that language learning experience was assumed to be directly related to WTC. Previous studies have consistently found that language learning experience is positively related to WTC (Khajavy et al., 2016; Peng \& Woodrow, 2010).

This finding, however, is not in line with some of the studies of previous research (e.g., Kim, 2009; Oz, Demirezen, \& Pourfeiz, 2014; Yashima, 2002; Yu, 2008). In contrast with the positive relationship between WTC and ideal L2 self, Yashima (2002), for example, reported a negative relationship between the aforementioned constructs. Moreover, Yu (2008) found a negative association between L2 learners' communication ability and their ideal L2 self. It is worth noting that these inconsistent findings may be 
related to different contextual variables involved and varying statistical techniques employed.

The research for the positive relationship between WTC and possible selves is that one's imagination to be a proficient learner may be related to an individual's willingness to communicate (Munezane, 2015). The learners who imagine more of their self-actualizing future selves using English as proficient speakers are more willing to communicate in an L2. More imagination leads to more willingness; therefore, elevating learners' ideal L2 self contributes to their communication behavior and makes them competent in using the target language (Al-Murtadha, 2019; Yashima, 2009). Thus, in order to become willing to communicate, learners need to visualize their ideal future selves as fluent language learners, thereby feeling more confident and becoming more willing to use the target language.

With respect to the second research question, the results of the study indicated that there was a statistically significant positive relationship between learners' WTC and their autonomy. In the literature on learner autonomy and WTC, the findings of this study are in line with those of a number of studies (Kang, 2005; Khaki, 2013). Similar to the present study, Khaki (2013) found a significant strong relationship between learner autonomy and trait-like WTC and a significant, but weak, correlation between learner autonomy and situational WTC in Iranian EFL learners.

However, the finding obtained from this study is in contradiction with what Scharle and Szabo (2000) found. They believe that autonomous learners just try to learn the subject matter and are not after pleasing teachers or influencing others; moreover, they are not eager for teamwork; they just do that for their benefit and that of others.

The positive relationship between learner autonomy and WTC could be related to instructors, learners, and syllabus designers' tendency toward moving the learning environment from the traditional artificial atmosphere to a more real-life experience. Accordingly, Zarrinabadi and Abdi (2011) highlighted that both WTC and learner autonomy were prerequisites for being successful in the language learning context, i.e., in order to be successful, an individual needs enhanced levels of learner autonomy and WTC. Another explanation of positive relationship between autonomy and WTC is the change in the role of the learners from passive participants to active ones in the classroom. Having an active role requires interaction and communication which is impossible without talk caused by WTC.

With regard to the third research question, the results of this study indicated that there was a positive relationship between WTC and academic target needs. In this regard, Taillefer (2007) and Kim (2009) highlighted the importance of speaking skills for the successful academic performance. Soodmand Afshar and Movassagh (2016) found that most students considered speaking skills important.

The positive relationship between academic target needs and WTC can be justified by the fact that WTC is supposed to facilitate the process of language learning and higher levels of WTC among learners lead to increased opportunity for authentic use of L2 (MacIntyre et al., 2001), which is truly needed in developing language (MacIntyre \& Legatto, 2011). Moreover, WTC influences not only speaking style but also reading, writing, and listening styles of language learners (MacIntyre et al., 1998). Additionally, as Peng (2007) asserted, a demanding program might have offered EAP learners the opportunity to get acquainted with the academic target needs; therefore, attitudes toward the language learning setting could have a greater impact on their WTC. 
According to the fourth research question, the results of a hierarchical multiple regression revealed that WTC, learner autonomy, and possible selves could be predictors of Iranian EAP learners academic target needs. Previous studies have highlighted the importance of WTC in an EAP context. According to Taillefer (2007) and Kim (2006), speaking skills for the successful academic performance are of great importance.

Accordingly, this finding confirms those of some other studies (Jordan, 2002), suggesting that one of the objectives of EAP is to provide language learners with autonomy to fulfil their needs. Alexander, Argent, and Spencer (2008) also found that realizing the expectations and needs of students while at the same time developing their autonomy on EAP courses was of great importance. Further, Broady and Kenning's (2000) study showed that helping students develop certain strategies that would allow them to achieve autonomy was worth attending to.

The reason that autonomy can significantly predict EAP learners' academic target needs may be due to the fact that autonomy can support learners to accept "the future challenges in academic or in professional life, can increase learning effects through personalization and higher motivation, enables learners to evaluate their own learning styles, cultivates self-confidence and prepares the learners to take control of the entire learning process" (Jamil, 2010, p. 50).

WTC can also significantly predict EAP learners' academic target needs because WTC is one of the best variables of success in L2 learning; therefore, learners with high levels of WTC might have greater opportunity to improve L2 proficiency (Kim, 2009). Likewise, it is argued that the most significant objective of L2 learning should be to engender in language students the willingness to communication (MacIntyre et al., 1998).

Finally, possible selves can significantly predict Iranian EAP learners' academic target needs since possible selves represent individuals' ideas of what they would like to be and what they are worried to become (Dornyei, 2005). Moreover, the findings in this regard can be justified by the fact that clear understanding of learners' needs in the English courses would improve their motivation and bring about better and faster learning.

\section{Conclusions}

The results of the study suggest that as students' WTC increases, their motif to communicate goes up as well. According to this result, one's image to be a proficient learner is related to his/her willingness to communicate in an L2. Accordingly, trying to elevate learners' ideal L2-self can contribute to their communication behavior and make them more competent users of the target language.

According to another finding of the study, WTC correlates positively with learner autonomy. In other words, students are willing to communicate when they become autonomous. Iranian students are not given much freedom in learning contexts, and they are accustomed to be told what to do passively without any objection, which could lead to a sense of confusion and uncertainty that autonomous students experience when they are given the freedom to make decisions in the learning process. Thus, by involving learners in the learning process they become more autonomous and, as a result, they are more willing to communicate and participate in language classes.

The third finding of the study was that there was a positive relationship between WTC and academic target needs in an EAP context. The main objective of English classes 
at undergraduate levels is to help students increase their technical vocabulary, reading, and translation skills. By providing opportunities for involvement and interaction among students in EAP classes, their WTC increases. Using new teaching methods and creating positive atmosphere in EAP classes improve their willingness to use the target language as well.

Finally, the results indicated that WTC, autonomy, and possible selves were the predictors of academic target needs. Hence, it can be concluded that not paying sufficient attention to EAP learners' WTC, autonomy, and possible selves in the context of Iran might lead to their ineffectiveness to fulfil their academic target needs. As Dornyei (2005) asserts, "WTC is a means and an end at the same time" (p. 210). Therefore, learners with a strong WTC may be able to effortlessly identify their academic target needs because a higher level of WTC among EAP learners translates into more opportunity for practice in an L2 (MacIntyre et al., 2001).

Fostering EAP learners' autonomy is one important way in helping them identify their academic target needs. Moreover, learners' engagement in a university, as a result of having a high level of possible selves, is obviously influenced by, and in turn impacts, who EAP learners think they actually are, who they consider they dream to be, and who they essentially become (Bojari, 2016; Meihami \& Salite, 2019).

\section{Implications}

Building on the findings of the study, we can discuss the following implications for sustainable development. For education to be sustainable, it requires being relatively stable. Autonomous, life-long learning, motivation to willingly participate in communicative events, and learners' inner feelings are three important factors, which may contribute to sustainable development. When language learners are autonomous, when they are well motivated to do learning, and when intrinsic and extrinsic factors are considered, language learning is much more enjoyable, and sustainability may be achieved.

Language learners' academic target needs should be identified to help them function more effectively in the target situations they will find themselves in their future lives. Identification of target needs may be considered helpful in achieving an acceptable degree of sustainable development, because in L2 pedagogy, when these needs are not known, teachers use their intuition, which may vary from one teacher to another and from one situation to another, thereby ruining the sustainable development that we can desire for.

\section{References}

Alexander, O., Argent, S., \& Spencer, J. (2008). EAP essentials: A teacher's guide to principals and practice. Reading UK: Garnet.

Alghamdi, A. K. H., \& El-Hassan, W. S. (2019). Raising Saudi students' (energy) sustainability awareness through ESL-teachers' thoughts. Journal of Teacher Education for Sustainability, 21(1), 137-154.

Al-Murtadha, M. (2019). Enhancing EFL learners' willingness to communicate with visualization and goal-setting activities. TESOL Quarterly, 53(1), 1-25.

Basturkman, H. (2006). Ideas and options in English for specific purposes. Mahwah, New Jersey: Lawrence Erlbaum Associates. 
Belcher, D. (2006). English for specific purposes: Teaching to perceived needs and imagined futures in worlds of work, study, and everyday life. TESOL Quarterly, 40(1), 133-156.

Benson, P. (2001). Teaching and researching autonomy in language learning. Harlow: Longman.

Bojare, I. (2016). Autonomous learning for English acquisition in blended e-studies for adults within the context of sustainable development. Journal of Teacher Education for Sustainability, 18(1), 11-126.

Brindley, G. (1989). The role of needs analysis in adult ESL program design. In R. K. Johnson (Ed.), The second language curriculum (pp. 63-78). Cambridge: Cambridge University Press.

Broady, E., \& Kenning, M. M. (2000). Promoting learner autonomy in university language teaching. London: Association for French language studies.

Brown, J. D., Collins, A., \& Duguid, P. (1990). Situation cognition and the culture of learning. Educational Researcher, 18(1), 32-42.

Cotterall, S., \& Crabbe, D. (Eds.). (1999). Learner autonomy in language learning: Defining the field and effecting change. New York \& Paris: Peter Lang.

Dornyei, Z. (2003). Attitudes, orientations, and motivations in language learning: Advances in theory, research, and applications. Language Learning Journal, 53(1), 3-32.

Dornyei, Z. (2005). Motivation and self-motivation. In S. M. Gass, J. Schachter, \& A. Mackey (Eds.), The psychology of the language learners (pp. 66-118). Mahwah, NJ: Lawrence Erlbaum.

Dornyei, Z. (2009). The L2 motivational self-system. In Z. Dornyei, \& E. Ushioda (Eds.), Motivation, language identity and the L2 self (pp. 9-42). Bristol, UK: Multilingual Matters.

Dudley-Evans, T., \& St John, M. J. (1998). Developments in English for specific purposes: A multi-disciplinary approach. Cambridge: Cambridge University Press.

Eddy-U, M. (2015). Motivation for participation or non-participation in group task: A dynamic systems model of task-situated willingness to communicate. System, 50, 43-55.

Hutchinson, T., \& Waters, A. (1987). English for specific purposes: A learning-centered approach. Cambridge: Cambridge University Press.

Jamil, M. G. (2010). Promoting learner autonomy on a university course of English for academic purposes: A BRAC university case study. BRAC University Journal, 7(1), 43-52.

Jordan, R. R. (2002). The growth of EAP in Britain. Journal of English for Academic Purposes, 1(1), 69-78.

Kang, S. J. (2005). Dynamic emergence of situational willingness to communicate in a second language. System, 33(2), 277-292.

Khajavy, G. H., Ghonsooly, B., Fatemi, A. H., \& Choi, C. W. (2016). Willingness to communicate in English: A microsystem model in the Iranian EFL classroom context. TESOL Quarterly, 50(1), 154-180.

Khaki, S. (2013). The relationship between learner autonomy and willingness to communicate (WTC) in Iranian EFL learners. International Journal of Applied Linguistics \& English Literature, 2(5), 98-109.

Kim, T.-Y. (2009). The sociocultural interface between ideal self and ought-to self: A case study of two Korean students' ESL motivation. In Z. Dornyei, \& E. Ushioda 
(Eds.), Motivation, language identity and the L2 self (pp. 274-294). Multilingual Matters: Clevedon.

Kong, J. H., Han, J. E., Kim, S., Park, H., Kim, Y. S., \& Park, H. Y. (2018). L2 motivational self-system, interactional posture and competitiveness of Korean CTL and LCTL college learners: A structural equation modeling approach. System, 72, 178-189. Long, M. H. (2005). Overview: A rationale for needs analysis and needs analysis research. In M. H. Long (Ed.), Second language needs analysis (pp. 1-16). Cambridge: Cambridge University Press.

MacIntyre, P. D., \& Doucette, J. (2010). Willingness to communicate and action control. System, 38(2), 161-171.

MacIntyre, P. D., Baker, S. C., Clement, R., \& Conrod, S. (2001). Willingness to communicate, social support, and language learning orientations of immersion students. Studies in Second Language Acquisition, 23(3), 369-388.

MacIntyre, P. D., Burns, C., \& Jessome, A. (2011). Ambivalence about communicating in a second language: A qualitative study of French immersion student's willingness to communicate. The Modern Language Journal, 95(1), 81-96.

MacIntyre, P. D., Clement, R., Dornyei, Z., \& Noels, K. A. (1998). Conceptualizing Willingness to communicate in a L2: A situational model of L2 confidence and affiliation. The Modern Language Journal, 82(4), 545-562.

Mazdayasna, G., \& Tahririan, M. H. (2008). Developing a profile of the ESP needs of Iranian students: The case of students of nursing and midwifery. Journal of English for Academic Purposes, 7(4), 277-289.

Meihami, H., \& Salìte, I. (2019). EFL teachers' cultural identity development through participating in cultural negotiation: Probing EFL students' perspective. Journal of Teacher education for Sustainability, 21(1), 115-127.

Munezane, Y. (2015). Enhancing willingness to communicate: Relative effect of visualization and goal setting. The Modern Language Journal, 99(1), 175-191.

Noels, K. A. (2003). Learning Spanish as a second language: Learners orientations and perceptions of their teachers' communication style. In Z. Dornyei (Ed.), Attitudes, orientations, and motivations in language learning (pp.97-136). Blackwell: Oxford.

Oz, H., \& Bursali, N. (2018). The relationship between L2 motivational self-system and willingness to communicate in learning English as a foreign language. Journal of Language and Linguistic studies, 14(4), 1-11.

Oz, H., Demirezen, M., \& Pourfeiz, J. (2014). Willingness to communicate of EFL learners in Turkish context. Learning and Individual Differences, 37, 269-275.

Papi, M. (2010). The L2 motivational self-system, L2 anxiety, and motivated behavior: A structural equation modeling approach. System, 38(3), 467-479.

Peng, J. (2007). Willingness to communicate in an L2 and integrative motivation among college students in an intensive English language program in China. University of Sydney Papers in TESOL, 23(3), 33-59.

Peng, J. E. (2015). L2 motivational self-system, attitudes, and affect as predictors of L2 WTC: Some imagined community perspectives. The Asia-Pacific Education Researcher, 24(2), 433-443.

Peng, J. E., \& Woodrow, L. (2010). Willingness to communicate in English: A model in the Chinese EFL classroom context. Language Learning, 60(4), 834-876.

Robinson, P. (1991). ESP today: A practitioners' guide. New York: Prentice Hall. 
Sato, R. (2017). Fluctuations in an EFL teacher's willingness to communicate in an English-medium lesson: An observational case study in Japan. Innovation in Language Learning and Teaching, 13(2) 105-117. doi: 10.1080/17501229.2017.1375506

Scharle, A., \& Szabo, A. (2000). Learner autonomy: A guide to developing learner responsibility. Cambridge: Cambridge University Press.

Soodmand Afshar, H., \& Movassagh, H. (2016). EAP education in Iran: Where does the problem lie? Where are we heading? Journal of English for Academic Purposes, $22,132-151$.

Taillefer, G. F. (2007). The professional language needs of Economics graduates: Assessment and perspectives in the French context. English for Specific Purposes, 26(2), 135-155.

Ushioda, E. (1996). Developing a dynamic concept of motivation. In T. J. Hickey (Ed.), Language, education, and society in a changing world (pp. 239-245). Clevedon, England: Multilingual matters.

Ushioda, E. (2011). Language learning motivation, self and identity: Current theoretical perspectives. Computer Assisted Language Learning, 24(3), 199-210.

Yashima, T. (2002). Willingness to communicate in a second language: The Japanese EFL context. The Modern Language Journal, 86(1), 54-66.

Yashima, T., MacIntyre, P. D., \& Ikeda, M. (2016). Situated willingness to communicate in an L2: Interplay of individual characteristics and context. Language Teaching Research, 22(1), 115-137.

$\mathrm{Yu}$, M. (2008). Willingness to communicate of foreign language learners in a Chinese setting (Unpublished Doctoral Dissertation). Florida State University, Tallahassee.

Yung, K. W. H. (2019). Exploring the L2 selves of senior secondary students in English private tutoring in Hong Kong. System, 80, 120-133.

Zarrinabadi, N., Ketabi, S., \& Tavakoli, M. (2017). Using person-centered future time perspective intervention to enhance EFL learner's willingness to communicate. RELC Journal, 1-9. doi: 10.1177/0033688217716536.

Zhang, J., Beckmann, N., \& Beckmann, J. F. (2018). To talk or not to talk: A review of situational antecedents of willingness to communicate in the second language classroom. System, 72, 226-239.

Zhang, L. X., \& Li, X. X. (2004). A comparative study on learner autonomy between Chinese students and west European students. Foreign Language World, 4(1), 15-23.

Zhou, M. (2016). The role of social anxiety, autonomy, and learning orientation in second language learning: A structural equation modeling analysis. System, 63, 89-100.

Zygmunt, T. (2016). Language education for sustainable development. Discourse and Communication for Sustainable Education, 7(1), 112-124. doi: 10.1515/dcse-20160008. Retrieved from https://content.sciendo.com/view/journals/dcse/7/1/ articlep112.xml

Correspondence concerning this paper should be addressed to Rajab Esfandiari, Assistant Professor of Applied Linguistics at the Department of English Language, Faculty of Humanities, Imam Khomeini International University, 3414896818, Qazvin, Iran. E-mail: esfandiari@hum.ikiu.ac.ir 